\title{
Corporate governance mechanisms and earnings management in Nigerian food product companies
}

\author{
Igodo Ogbonnaya Eze ${ }^{*}$
}

Department of Accountancy, Jigawa State Polytechnic Dutse, Nigeria

\author{
Index Terms \\ Corporate governance \\ Earnings management \\ Institutional shareholdings
}

Received: 17 September 2016

Accepted: 10 November 2016

Published: 27 February 2017

\begin{abstract}
One of the major challenges facing investors now is how to mitigate earnings management. Therefore, this research paper tries to find out whether this can be achieved through the application of corporate governance mechanisms. A sample of six (6) firms was selected out of eleven (11) firms in the Nigerian food product firms. The data were sourced from yearly report and account of selected firms for a period of twelve years (12), starting from 2003 to 2014. Descriptive statistics and correlation technique were employed in the analysis of data collected. A panel data regression technique was used because the data had time series and cross sectional attributes. It was found that board meeting has negative impact on earnings management; board gender and institutional ownership have negative relationship with earnings management while audit committee meeting has positive impact on earnings management. Size of the firm which is the control variable has positive effect on earnings management. The findings support the application of corporate governance principles as they motivate institutions to ensure that earnings management practice in Nigerian food product firms is adequately supervised. The study adopts agency theory which believes in bringing managers and shareholders to have a common understanding, thereby reducing agency cost. Therefore, the study recommends that institutional shareholdings should be encouraged as this would help to reduce the extent of earnings management in Nigerian food product firms.
\end{abstract}

(C) 2017 The Author(s). Published by TAF Publishing.

\section{INTRODUCTION}

Earnings Management (EM) has become an issue that is drawing serious attention from researchers, investors and government, which is a consequence of owners being distinct from managers of business. This separation has made it mandatory for managers (agent) to communicate their performance to the owners (principal). This can be achieved through the preparation and presentation of financial statements by the managers. It is expected of the managers to furnish the owners with quality, relevant and reliable financial information which could enable them to make an economic decision. But this seems to be difficult because of information asymmetry, in which the managers tend to concentrate more on what benefits them to the detriment of shareholders. However, divergence of interest between these two parties (principal and agent) has made the agent to take advantage of the loopholes and flexibility stipulated by accounting principles to manage income opportunistically, thus altering reported earnings which adversely affect the credibility and integrity of financial information. The effort to align these interests has been unsuccessful and has resulted to agency cost. In line with this, Man \& Wong (2013) defined EM as the decision of those at the helm of affairs of an organization to deliberately influence earnings. Abdullahi (2015) stated four things that can make managers to influence earnings as follows: to meet regulatory requirement, capital market requirements, bonus and other remunerations and external

\footnotetext{
* Corresponding author: Igodo Ogbonnaya Eze

†Email: eze.igodo@yahoo.com
} 
reasons. Therefore, the power of agents to exhibit opportunistic behavior in the management of an organizations earnings can be restrained by having adequate and effective ownership structure, board and audit committee which are necessary element of Corporate Governance (CG) (Klein, 2000; Chtourou, Bedard \& Courteau, 2001; Liu \& Lu, 2007; Samaila, 2014; Abdullahi, 2015; Purnamasari \& Fitdiarini, 2016; Na Ayutthaya, Tuntivivat \& Prasertsin, 2016; Dianita, 2015).

However, Hamid (2009) sees CG as the structure through which the activities of an organization is being managed. Moreso, Abdullahi (2015) stated that ineffective $\mathrm{CG}$ is the beginning of the failure of many businesses. This could be seen in the case of Enron in United States, which hid billions of dollars of debt from its shareholders in failed deals and project and the shareholders lost more than $\$ 60$ billion in the year 2001. WorldCom in United States in 2002 overstated its cash flows; Parmalat in Italy in 2003 falsified its accounting documents and Cadbury Nigeria Plc. in 2006 falsified their financial documents. It is expected that effective CG will bring about a better corporate performance.

However, financial difficulties that took place in Asia in 1990s have exposed us to the need for CG practices (Hashim \& Devi, 2008). In reaction to this, countries like Malaysia introduced and mandated compliance with Code of CG. Other countries followed the Malaysian example: Chinese in 2001, Pakistan in 2002 and Nigeria in 2003 and 2006 for other public companies and banks respectively (Abdullahi, 2015). However, for the board to be active in its management control as well as mitigating earnings management, it must hold regular meetings, have adequate number of female representatives, be independent, and ensure there is separation of power.

The Nigerian food product firms occupy important positions in the Nigerian economy and contribute immensely to the development of the country. This is a sub sector of consumer goods sector. It is increasing rapidly and we believe opportunities still exist in this subsector. But the failure of Cadbury Nigeria plc in 2006, in which the company was found to have altered the accounting documents, made investors doubt the earning quality of firms in this subsector. This practice clearly indicates the presence of devious practice and throws doubt on the functions of CG structure in mitigating EM in Nigerian food product firms. However, it is clear from the knowledge of the researcher that previous studies on CG and EM above have documented mixed results which allow for further research on this topic; this study has distinguished itself from other studies in the fol- lowing ways: (i) No previous research exists on the CG mechanisms and EM that has covered a period between 2003 and 2014. (ii) None of the previous studies on this area covered Nigeria food product sub-sector of consumer goods. (iii) None of the previous studies used a combination of board attributes, audit committee attributes and inside and outside ownership as CG mechanisms i.e. (board meeting, board gender, audit committee meeting and institutional ownership). The research paper focuses on impact and relationship that CG has on EM. In line with this, agency theory practically explains CG and EM especially in the manufacturing companies where the basic tenet of CG is to protect the interest of the owners (shareholders) who are also the principal of the management (agents).

However, this study adopts agency theory alongside (Asuagwu, 2013; Abdullahi, 2015; Latif \& Abdullah, 2015). Therefore, the rest of the paper is put together in the following order: review of documented literatures is in section two, research design, population of study, sample size and how data were sourced are in section three, analysis and interpretation of data are in section four while findings, recommendations frontier for future research and conclusions are in section five.

\section{LITERAT URE REVIEW}

\section{Corporate Governance}

A good number of literatures available on this subject have defined CG in so many ways. According to Asuagwu (2013), CG is a structure used to reduce agency costs which occur as result of distinct interest between principals and agents. But according to Hamid (2009), there is no generally accepted definition of CG which enjoys consensus of opinion in all settings and countries of the world. Therefore, CG can simply be defined as the process through which an organization is being directed and controlled to ensure maximum protection of shareholders' interest. However, Wilson (2006) in his own view added that CG is about the manner in which corporations are directed, controlled, and held to account for the resources used.

According to O'Donovan (2003), CG is an in-house structure designed to direct and control management functions by being knowledgeable, objective and accountable in ensuring that shareholders' and stakeholders' investments are protected. In the same line, Kurawa (2013) maintains that CG is the mechanism that safeguards the shareholders' interest which is necessitated as a result of separation between the owners of business and managers of business. Therefore, from the above definitions, CG can be seen as 
the structures established by an organization to inculcate corporate discipline, transparency and accountability in the management of employees of an organization to enable them safeguard the assets of the organization adequately and above all protects the interest of shareholders.

\section{Earnings Management}

EM has become an important area of research as it is capable of undermining the value of accounting documents that can pass relevant facts to investors in an organized financial market. But to Abdullahi (2015) EM involves the choice of accounting policies employed by managers to achieve their self-interest by misleading stakeholders via presenting distorted financial statements. The need behind EM is the basis of agency problem. Managers have different advantages for engaging in EM practices, ranging from their remunerations to external contractual benefits. This basically happens because there is divergence of interest between agents (managers) and principal (owners). And whenever managers exhibit devious attitude, owners will be left in doubt on any financial or accounting document presented to them; which realistically makes it difficult for them to make an informed economic decision.

According to Musa \& Luka (2014), EM could come from freedom of choices provided by accounting principles. Accounting principles allow agents (managers) of firms to select among various reporting procedures and make assumptions in view of the peculiarity of their business environment. On the other hand, Akers, Giacomino \& Bellovary (2007) defined EM to be efforts made by managers to alter earnings of firms either by using a particular method of accounting or replacing method, considering a single time non-returning items or other methods that could be used in a short term period to affect earnings. But Man \& Wong (2013) defined EM as the decision of those at the helm of affairs of an organization to deliberately influence earnings. Gulzar (2011) on their own viewed EM as an alteration of reported firms' activities by those within the firm either to misguide those that have economic interest in the firm or to achieve other targets.

However, it is expected that agency theory could bring both the agents and principals together by ensuring a common understanding between them. If this is done, agency cost will be reduced drastically. Therefore, from the forgoing definitions, EM can be seen as deliberate action taken by the management to alter the real reported economic value of the organization in order to protect their interest.

\section{Empirical Studies on Board Meeting and Earnings Man- agement}

The role played by board size and independence is quite understandable but it is not enough mechanism in curtailing EM. The board needs to meet frequently to discuss important issues for it to be effective in the discharge of its responsibilities. This means that board meeting is another important mechanism to be considered while mitigating EM. In line with this, various researchers on this have come up with mixed result; among them are: Xie, Davidson III \& DaDalt (2003) found out that BM is negatively related to EM. However, Vafeas (2000) empirically stated that there is direct relationship between BM and EM. Garcia Lara, Garcia Osma \& Penalva (2009) stated that board meeting could be an appropriate measure that can help directors in their supervisory functions. Gulzar (2011) and Abdel Razek (2012) found board meeting to be negatively related to EM. Latif \& Abdullah (2015) recorded that board meeting has negative and insignificant impact on EM. The literature clearly documented that board meeting is an important mechanism that could mitigate EM since it serves as an avenue where board members meet to deliberate on vital issues that will help in attaining firm aims thereby curtailing EM practices. It is expected that regular meeting of the board could help to mitigate EM.

\section{Empirical Studies on Board Gender and Earnings Man- agement}

A lot of researchers have expressed various views over female participation as directors in firms. Abdullahi (2015) documented that the women director representative in Nigerian cement firms has negative but insignificant effect on the EM behavior of these firms. On the other hand, Tijjani \& Dabor (2010) found that the composition of women directors in the board had a negative relationship with EM and a positive relationship with firm performance but had no significant impact. Emmilia \& Sami (2010) and Adams \& Ferreira (2009) could not find any relationship between EM and gender of firms. Adams \& Ferreira (2009) further claimed that women appointed as directors may be more careful and seek greater accountability for than their male colleagues. Furthermore, women directors can think more independently compared with male directors and also effectively monitor chief executive officer behavior (Carter, Simkins \& Simpson, 2003). Fondas \& Sassalos (2000) argued that board that is made up of only a particular gender may not perform better than the one that accommodates 
both genders. They believed that incorporating women in the board would add value to firms. Women are participating more in corporate boards; recently researchers have started providing more evidences for women participation in board. Furthermore, Sunden \& Surette (1998) also found similar result. Therefore, directors would make sure that managers don't behave in way to bring their reputation down. Furthermore, Powell \& Ansic (1997) provide evidence of women being less risk seeking in their actions. However, looking at the literature, a mixed result is recorded as some are of the view that allowing women to participate in board will bring better management performance while some are of the view that having women in the board is not necessary. It is therefore expected that having adequate number of female representatives will help mitigate EM, since women always demand for accountability even in their homes than their men counterparts.

\section{Empirical Studies on AC Meeting and Earnings Man- agement}

Researchers have recorded different views on the function of AC meeting in curtailing EM. Audit committee meeting could be seen as an avenue where members discuss and react to the issues observed by the auditors of the firm, such as letter of internal control weakness. However, Abdullahi (2015) found ACM to be positively and insignificantly related to EM. Empirical evidence shows that the meeting frequency of audit committee management practice impairs EM. Erena \& Tehulu, (2012) found that ACM is negatively related to EM. Moreso, Xie et al. (2003) also found ACM to have negative impact on EM. More so, in Nigeria, section 359 sub sections 3 and 4 of CAMA, 2004 stipulated that audit committee could have not less than 3 meetings yearly . Similarly, Roodposhti \& Chashmi (2001) suggests that AC can hold not less than 4 meetings annually and should provide for special meetings when there is need.

In line with this argument, National Association of Corporate Directors also recommends that "The audit committee should meet as frequently as necessary to perform its role". However, BRC and US SEC regulations do not specify how often the AC should meet, but the guideline for AC meetings in the UK specifically stipulated that ACM depends on the business operations of the firms. The guidelines stipulate that ACM be held in-between the end of annual audit and starting another year's audit, and before a temporary statement is rendered after the interim statement and after year end, but before the accounts are finalized. Impliedly, the committee is to meet not less than four times in a year.
Looking at the documented literatures, it could be considered that frequent meeting by the firms' auditors will contribute in reducing the extent of EM.

\section{Institutional Ownership and Earnings Management}

INSTOWN have to be actively involved in considering the terms and scheme of service of directors. A lot of researchers have recorded mixed result in trying to establish the importance of institutional ownership in mitigating EM. It has been found from previous studies that INSTOWN discharges crucial function to ensure that firms are better directed, organized and controlled by supervising the activities of the agents in the firm (Shleifer \& Vishny, 1986; Coffee Jr. 1984). In line with this, INSTOWN exercises supervisory role on the activities of members of audit committee to ensure that they carry out their duties accordingly. However, studies like (Jeanjean, 2000; Bradbury, Mak \& Tan, 2006; Park \& Shine, 2004; Dimitrpoulous, 2011; Roodposhti \& Chashmi, 2011; Alves, 2012; Chekili, 2012) found that firms with higher and effective INSTOWN are engaged in less EM. While (Hashim \& Devi, 2010; Mansourinia, Emamgholipour, Rekabdarkolaei \& Hozoori, 2013; González \& García-Meca, 2014; Latif \& Abdullah, 2015) found INSTOWN to be positively related to EM. Furthermore, institutional ownership seems to be better informed than individual ownership. This is because institutional ownership studies activities of firms better than other forms of ownership. Therefore, it is expected that institutional shareholders will contribute to a great extent in mitigating EM.

\section{RESEARCH METHODOLOGY}

\section{Research Design}

The research paper used non-survey design. This is because all the variables needed for the research were extracted from yearly report and account of the Nigerian food product firms listed on Nigeria stock exchange. And the study covers twelve years from 2003 to 2014.

\section{Population and Sample Size}

The population of this study covers all the eleven (11) food products firms of consumer goods listed on the floor of the Stock Exchange in Nigeria as at 2014. The sample of six (6) firms was selected out of the population. Therefore, for any firm to be qualified for this study, the firm must be listed on Nigeria stock exchange on or before 30th December, 2002 and must have not been delisted within $2003-2014$. The need for this filter is to enable the researcher get complete set of data to cover the period of study. The sample size 
is the six firms that qualified after adopting the filter and are as follows: Flour mills, NNFM PLC, National Salt, Union Dicon, Ps Mandrides and UTC. This is considered adequate to eliminate sampling risk and enhance users' confidence in the result of the study (Ahmed, 2012) as cited in (Abdullahi, 2015).

\section{Variables and their Measurements}

Dependent variable which is EM is proxy by discretionary accruals. However, following the prior studies, it was observed that adjusted Jones model (1991) proposed by Dechow, Sloan \& Sweeney (1995) is mostly used model to detect EM. It is also used in this research paper. This agrees with the studies of (Xie et al., 2003; Abudullahi, 2015).

\section{Explanatory Variables}

The explanatory variable of this study is made up of independent and control variables.

\section{Independent variables}

Independent variables are Board Meeting, Wo men Director, Audit Committee Meeting and Institutional Ownership.

Board Meetings (BM): this means number of times the board held its meeting within the year.

Board Gender (BG): this is the proportion of women directors in the board.

Audit Committee Meeting (ACM): this means how many meetings held by members within the year.

Institutional Ownership (ISO): this means number of shares of firms held by institutions.

\section{Control variables}

The control variable in this study is firm size, calculated using natural log of total assets. This is in harmony with Abdullahi (2015).

\section{Model Specification}

In line with recorded literatures Thus, this regression equation could be expressed as follows:

$\mathrm{EM}=\beta 0+\beta 1 \mathrm{BM}+\beta 2 \mathrm{BG}+\beta 3 \mathrm{ACM}+\beta 4 \mathrm{ISO}+\beta 5 \mathrm{FS}+\varepsilon \mathrm{it}$

Where:

$\mathrm{EM}=\mathrm{EM}$

$\mathrm{BM}=$ Board Meeting

$\mathrm{BG}=$ Board Gender

$\mathrm{ACM}=$ Audit Committee Meeting

ISO = Institutional Ownership

FS $=$ Firm Size

$\beta o=$ parameters $\varepsilon=$ Error term

$\beta 1-\beta 5=$ Gradient of Independence

\section{RESULT S AND DISCUSSION}

Results and findings are discussed here. The study uses regression model.

TABLE 1 . Descriptive statistics

\begin{tabular}{|c|c|c|c|c|c|}
\hline Variable & Observation & Mean & S.D & Minimum & Maximum \\
\hline Em & 72 & - & 0.652198 & -2.2834 & 1.8886 \\
\hline $\mathrm{Bm}$ & 72 & 0.1427 & 5 & 2 & 6 \\
\hline Bgender & 72 & 597 & 0.944053 & 0 & 0.2222 \\
\hline $\mathrm{Acm}$ & 72 & 3.8055 & 1 & 2 & 4 \\
\hline Iso & 72 & 56 & 0.061617 & 0.5771 & 0.8488 \\
\hline \multirow[t]{8}{*}{ Fsize } & 72 & 0.0695 & 5 & 4.095727 & 8.911425 \\
\hline & & 778 & 0.812533 & & \\
\hline & & 2.9583 & 9 & & \\
\hline & & 33 & 0.084257 & & \\
\hline & & 0.7163 & 1.403425 & & \\
\hline & & 917 & & & \\
\hline & & 6.8126 & & & \\
\hline & & 38 & & & \\
\hline
\end{tabular}

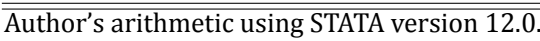

The table 1 is about descriptive statistics of all variables used. It shows minimum, maximum, mean, and standard deviation. The dependent variable average is -0.14 while standard deviation is 0.65 which indicates that the magnitude of EM among the sampled firms varies with least and highest being -2.28 and 1.89 respectively. The remaining variables which are all independent in the table show some level of changes. Generally, the highest average value and standard deviation of the independent variables is board meeting with 3.08 and 0.94 respectively, and board gender recorded the least average and standard deviation of 0.07 and 0.06 respectively.

TABLE 2 . Correlation matrix

\begin{tabular}{lccccccc}
\hline \hline Variable & EM & BM & BG & ACM & ISO & FS & VIF \\
\hline EM & 1.0000 & & & & & & \\
BM & -0.0659 & 1.0000 & & & & & 1.19 \\
BG & 0.0507 & 0.0601 & 1.0000 & & & & 1.43 \\
ACM & 0.0240 & 0.3198 & 0.1327 & 1.0000 & & & 1.24 \\
ISO & -0.3673 & 0.1460 & -0.4190 & 0.1927 & 1.0000 & & 1.33 \\
FS & 0.1752 & 0.1414 & -0.3510 & -0.1696 & 0.1513 & 1.0000 & 1.23 \\
\hline \hline
\end{tabular}

Author's arithmetic using STATA output.

The result of correlation matrix as shown in table 2 indicates that the coefficients of dependent and explanatory variables are 1.0000 along the primary diagonal. This is so because there exists positive relationship among independent variables. The correlation coefficient of board meet-

ing (BM) and EM (EM) is -0.066 . This implies that BM and 
EM are weakly and negatively correlated. The proportion of female representatives (BGENDER) on the board of Nigerian food product firms is weakly and positively correlated with EM as shown by the correlation coefficient of 0.051 . This is as a result of insignificant percentage $(7 \%)$ of female representatives compared to the number of male directors (93\%). The correlation coefficient of Audit committee meeting (ACM) and EM is 0.02. This result suggests a weak and positive correlation between ACM and EM. The correlation coefficient of institutional ownership (ISO) and EM is -0.37 .

This implies that institutional ownership (ISO) and EM are strongly and negatively correlated. There is a strong and positive correlation between firm size (FS) and EM throughout the study period for all the sampled firms as indicated by the correlation coefficient of 0.18 . However, all other explanatory variables except ISO and FS are positively related with themselves. ISO is strongly and negatively correlated with BGENDER as shown by the correlation coefficient of -0.42 . Similarly FS is strongly and negatively correlated with $B G$ and ACM as shown by the correlation coefficient of -0.35 and -0.17 respectively. Finally, the variance inflation factor (VIF) for all the explanatory variables ranges from 1.19 to 1.43 as shown in table 2 . This clearly indicates the absence of multicollinearity among the explanatory variables as 3.00 and 5.00 are still acceptable as proof of absence of multicollinearity (Samaila, 2014).

TABLE 3 . OLS regression results

\begin{tabular}{lcccc}
\hline \hline Variable & Coefficient & Std Error & T & P>t \\
\hline Constant & 1.39740 .8188 & 1.71 & 0.093 & \\
B & -0.6604 & 0.0817 & -0.81 & 0.422 \\
Bg & -0.7302 & 1.3707 & -0.53 & 0.596 \\
Acm & 0.1589 & 0.0971 & 1.64 & $0.107^{*}$ \\
Iso & -3.5677 & 0.9681 & -3.69 & $0.000^{* * *}$ \\
Fsize & 0.1244 & 0.5579 & $0.029^{* *}$ & \\
R-square & 0.2238 & & & \\
Adj R-squared & 0.1649 & & & \\
F-statistics & 3.80 & & & \\
Prob>F & 0.0043 & & & \\
\hline \hline Author's arithmetic using STATA (version 12.0). ${ }^{* * *},{ }^{* *}$ and ${ }^{*}$ indicate \\
1\%, 5\% and 10\% significant level.
\end{tabular}

To evaluate the model, the OLS result is used. The result indicates that board meeting has negative but insignificant impact on EM. It means that as the board holds its meeting frequently, EM is reduced. Board gender also has negative but insignificant impact on EM, which implies that as the

number of female representatives in the board increases, ISSN: 2414-309X

DOI: $10.20474 /$ jabs-3.1.1
EM decreases. Audit committee meeting has positive but significant relationship with EM. This means that as the audit committee meets regularly, EM is encouraged. However, size of the firm is positively and significantly related to EM. This means that as the firm increases in size, EM is 2 encouraged. The coefficient of determination (R2) of 0.22 indicates that $22 \%$ of the changes in (EM) are jointly de tailed by the changes in the explanatory variables; BM, BG, ACM, ISO and FS. This is confirmed by adjusted value of determination coefficient (Adj R2) of 0.16 showing that after adjusting for error term, $16 \%$ of the variations in EM of the sampled firms are jointly explained by the changes in BM, BG, ACM, ISO and FS.

\section{CONCLUSION AND RECOMMENDATIONS}

This research has considered impact of CG mechanisms on EM in Nigerian food product firms. Results show that frequency of board meeting has proven to be an effective way of mitigating EM in the Nigerian food product firms. The inadequate number of female representatives on the board of Nigerian food product firms has contributed to the insignificant impact of female directors on EM. The frequency of audit committee meeting does not mitigate EM in Nigerian food product firms. This owes to the fact that the more they meet, the more the independence of auditors is eroded.

Furthermore, institutional share ownership has proven to be an effective mechanism for curtailing EM. However, firm size does not curtail EM. It rather increases it, because as size of firms increases, EM also increases. So, through effective monitoring by the institutions, the interest of shareholders and management can be aligned which invariably will solve the agency problem. In view of the above conclusion, it is therefore recommended that institutions should be encouraged to own more shares; since they are better exposed to the activities of the firms and have the ability to monitor and influence the opportunistic actions of the managers than other forms of ownership structure. This research examines the impact of CG on EM in the Nigerian listed food product firms and has paved way for further research in the area.

Therefore, future research should focus on the relationship between CG and EM in other sectors of the economy such as financial services industry, ICT industry, services industry, health care industry, construction/real estate industry, conglomerates industry, natural resources industry and agricultural industry, especially as they are not covered in this work. In addition, same research can be conducted by bringing in other CG variables like managerial ownership, 
family ownership, government ownership, foreign ownership, CEO tenure, board compensation, board education and experience, board expertise, audit committee size, audit committee competence, diligence and leverage. Again, given that the research has limited his evaluations to cover a twelve year period (i.e., 2003-2014), future research in this area of accounting should consider it necessary to extend the periods studied so as to capture more recent global trends on CG and EM. Although the current study used quan- titative method of data collection, the qualitative methods were not undertaken in this study. However, using qualitative techniques, such as interviews and case studies, in addition to the quantitative, may improve our understanding to the issue of EM. Again, the base year for this study is 2003 which was when the code of CG became operational in Nigeria. Therefore, it will be good if the future research could consider a period before 2003 as base year.

\section{REFERENCES}

Abdel Razek, M. 2012. The association between earnings management and corporate governance-A survey from Egypt. Journal of Finance \& Accounting, 3 (8): 128-131.

Abdullahi, Z. 2015. Corporate board structure, audit committee attributes and earnings management of listed cement companies in Nigeria. Unpublished Master's thesis, Bayero University Kano Kano, NG.

Adams, R.B., \& Ferreira, D. 2009. Women in the boardroom and their impact on governance and performance. Journal of Financial Economics, 94(2): 291-309. D0I: 10.1016/j.jfineco.2008.10.007

Ahmed, E.M. 2012. Green TFP intensity impact on sustainable East Asian productivity growth. Economic Analysis \& Policy, 42(1): 67-78. DOI: 10.1016/S0313-5926(12)50005-6

Akers, M.D., Giacomino, D.E., \& Bellovary J.L. 2007. EM and its implications. The CPA Journal, 79(8): 64-68.

Alves, S. 2012. Ownership structure and EM: Evidence from portugal. Australian Accounting Business \& Finance Journal, 6(1): 57-74.

Asuagwu, G. 2013. Implication of CG on the performance of deposit money banks in Nigeria. Arabian Journalof Business \& Management Review, 2(10): 22-45.

Bradbury, M., Mak, Y.T., \& Tan, S.M. 2006. Board characteristics, audit committee characteristics and abnormal accruals. Pacific Accounting Review, 18(2): 47-68. D0I: 10.1108/01140580610732813

Carter, D.A., Simkins, B.J., \& Simpson, W. G. 2003. CG board diversity and firm value. Financial Review, 38(1): 33-53. DOI: $10.1111 / 1540-6288.00034$

Coffee Jr, J.C. 1984. Market failure and the economic case for a mandatory disclosure system. Virginia Law Review, 70(4): 717-753. DOI: $10.2307 / 1073083$

Chekili, S. 2012. Impact of some governance mechanism on EM: An empirical validation within Tunisian market. Journal of Business Studies Quarterly, 3(3): 95-104.

Chtourou, S. M., Bedard, J., \& Courteau, L., 2001. Corporate governance and earnings management. University of Laval, Quebec, CA.

Dechow, P. M., Sloan, R.G., \& Sweeney, A.P. 1995. Detecting earnings management. Accounting Review, 70(2): 193-225.

Dimitropoulos, P. 2011. CG and EM in the European football industry. European Sport Management Quarterly, 11(5): 495-523. DOI: $10.1080 / 16184742.2011 .624108$

Dianita, M. 2015. Role of the internal auditor influence and good corporate governance in banking financial performance against state owned corporation. International Journal of Business \& Administrative Studies, 1(4), 176- 179.

Emmilia, P., \& Sami, V. 2010. Female executives and EM. Journal of Managerial Finance, 36(7): 629-645. DOI: $10.1108 / 03074351011050343$

Erena, 0.T., \& Tehulu, T.A. 2012. The impact of CG mechanisms on EM: Evidence from banks in Ethiopia. International Journal of Researc in Commerce, Economics \& Management, 2(8): 2231-4245.

Fondas, N., \& Sassalos, S. 2000. A different voice in the boardroom: How the presence of women directors affects board influence over management. Global Focus, 12(2): 13-22.

Garcia Lara, J., Garcia Osma, B., \& Penalva, F. 2009. Accounting conservatism and CG. Review of Accounting Studies, 14(1): 161-201. DOI: $10.1007 / \mathrm{s} 11142-007-9060-1$ 
González, J. S., \& García-Meca, E. 2014. Does corporate governance influence earnings management in Latin American mar- $\quad$ kets? Journal of Business Ethics, 121(3): 419-440. D0I: 10.1007/s10551-013-1700-8

Gulzar, M.A. 2011. Corporate governance characteristics and earnings management: Empirical evidence from Chinese listed

firms. International Journal of Accounting \& Financial Reporting, 1(1): 133-138. D0I: 10.5296/ijafr.v1i1.854

Hamid, K.T. 2009. The nature of the relationship between cg and internalcontrol system: A study of Nigerian banking indus- $\quad$ try. Nigerian Jounal of Accounting \& Finance, 1(2): 881-906.

Hashim, H.A., \& Devi, S. 2008. Board characteristics, ownership structure and earnings quality: Malaysian evidence. Re- $\quad$ search in Accounting in Emerging Economies, 8(97): 97-123. DOI: 10.1016/S1479-3563(08)08004-3

Jeanjean, T. 2000. Corporate governance and earnings management. CEREG, University of Paris-Dauphine, FR.

Jones, J. 1991. EM during import relief investigation. Journal of Accounting Research, 29(2): 193-228.

DOI: $10.2307 / 2491047$

Klein, A. 2000. Audit committee, board of directors' characteristics and EM. Journal of Accounting \& Economics, 33(3):

375-400. DOI: 10.1016/S0165-4101(02)00059-9

Kurawa, J.M. 2013. Effect of corporate governance on corporate social responsibility of listed firms in the Nigerian

petroleum marketing industry. Paper presented at 5th international conference on corporate governance: Gover-

nance of public and private sector.

Latif, A.S., \& Abdullah, F. 2015. The effectiveness of corporate governance in constraining earnings management in Pakistan.

The Lahore Journal of Economics, 20(1): 135-155.

Liu, Q., \& Lu, Z. 2007. CG and EM in Chinese listed companies: A tunneling perspective. Journal of Corporate Finance, 13 :

881-906. DOI: 10.1016/j.jcorpfin.2007.07.003

Man, C.K., \& Wong, B. 2013. Corporate governace and earning managemnt: A survey of literature. The Journal of Applied

Business Research, 29(2): 234-238. DOI: 10.19030/jabr.v29i2.7646

Musa, A. F., \& Luka, M. 2014. Corporate Governace Mechanism and EM of Listed Oil and Gas Companies in Nigeria: The cer- tified national accountant. A b-monthly Journal of the Association of National Accountants of Nigeria, March-

April, $\quad 42-46$.

Mansourinia, E., Emamgholipour, M., Rekabdarkolaei, E. A., \& Hozoori, M. 2013. The effect of board size, board indepen- dence and CEO duality on dividend policy of companies: Evidence from Tehran Stock Exchange. International Journal of Economy, Management \& Social Sciences, 2(6): 237-241.

Na Ayutthaya, J. S., Tuntivivat, S., \& Prasertsin, U. 2016. The effect of positive psychological capital and organizational climate on service quality: The mediation role of work engagement of hotel service employees in Ratchaburi province. Journal of Administrative \& Business Studies, 2(4): 167-176.

O'Donovan, G. (2002). Environmental Disclosures in the Annual Report: Extending The Applicability and Predictive Power of Legitimacy Theory. Accounting, Auditing \& Accountability Journal, 15(3), 344-371.

DOI: $10.1108 / 09513570210435870$

Park, Y.W., \& Shin, H.H. 2004. Board Composition and EM in Canada. Journal of corporate finance, 10(3): 431-457.

DOI: $10.1016 /$ S0929-1199(03)00025-7

Powell, M., \& Ansic, D. 1997. Gender differences in risk behaviour in financial decision making: An experimental analysis.

Journal of Economic Psychology, 18(6): 605-28. DOI: 10.1016/S0167-4870(97)00026-3

Purnamasari, K., \& Fitdiarini, N. 2016. Corporate diversification and cash holding. Journal of Administrative \& Business Studies, 1(1), 21-27.

Roodposhti, F. R., \& Chashmi, S.A.N. 2011. The impact of CG mechanisms on EM. African Journal of Business Management, 5(11): 4143-4151.

Samaila, A.I. 2014. CG and financial reporting quality. An analysis of Nigeria petroleum marketing companies. Unpub- lished doctoral dissertation, Bayero University Kano, NG.

Shleifer, A., \& Vishny, R. 1986. Large shareholders \& corporate control. Journal of Political Economy, 94(3): 461-489.

DOI: $10.1086 / 261385$

Sunden, A.E., \& Surette, B.J. 1998. Gender differences in the allocation of assets in retirement savings plan. American Eco- $\quad$ nomic Review, 88(2): 201-211. 
Tijjani, B., \& Dabor, E.L. 2010. The impact of EM and CG on firm performance. Bayero International Journal of Accounting Research, 4(1):209-234.

Vafeas, N. 2000. Board structure and the informativeness of earnings. Journal of Accounting \& Public Policy, 19 (2). 139- 160. DOI: 10.1016/S0278-4254(00)00006-5

Wilson, I. 2006. Regulatory and institutional challenges of corporate governance in Nigeria post banking consolidation.

Nigerian Economic Summit Group Economic Indicators, 12 (2): 1-10.

Xie, B., Davidson III, W.N., \& DaDalt, P.J. 2003. EM and CG: The role of the board and the audit committee. Journal of Corpo- rate Finance, 9(3): 295-316. DOI: 10.1016/S0929-1199(02)00006-8

— This article does not have any appendix. - 